\title{
Bridging the Gap between Language and Literature: Teaching English in Bangladesh at Tertiary Level
}

\author{
Masrufa Ayesha Nusrat \\ manusrat@ewubd.edu
}

East West University, Bangladesh

\begin{abstract}
Using literary material for developing language skills has gained new attention for both L1 and L2 learners in the last two decades. In my paper I would like to explore the possibilities and loopholes of teaching language through literature in Bangladesh at the tertiary level. Our language classes follow traditional lecture-based teaching techniques and use almost no literary materials for teaching language. Mostly 'referential' materials are taught by Communicative Language Teaching (CLT) method which are exclusively confined to everyday real-life situational use and does not engage learners' imaginative faculties. Therefore, I have tried to demonstrate how literary texts or 'representational texts' can develop English proficiency, foster critical thinking and encourage creative language use. I have also critiqued our material selection; teaching approaches; evaluation; and rote learning during exam. As a result a gap has long been created between language and literature at the tertiary level, hampering language acquisition. Although critical practices like, Literary Theory and Cultural Studies, have enriched our academia and generated impressive curriculum (such as World Literature in English, Comparative Literature and Applied Linguistics and ELT), learners' basic linguistic competence has declined considerably. I have tried to recommend ways to solve these problems by introducing language-based teaching approach and integrating language with literature.
\end{abstract}

Keywords: representational material, referential material, language-based approach, stylistics, literature with a small 'l', literary language, imaginative language use, literary and linguistic competence, product-based and processbased teaching and learning

\section{INTRODUCTION}

English is taught both as a specialized subject and mandatory language requirement for all disciplines in public and private universities at tertiary level in Bangladesh. Most language classes traditionally use 'referential teaching material' and communicative language teaching (CLT) method which hinders learners' adequate language acquisition. These materials are not authentic and do not engage learners' imaginative faculty, creative 
language or critical thinking. 'Referential' texts lead to one dimensional learning because it is transaction-based, socially conditioned and limited to everyday use. These materials based on survival learning are unable to teach different range of linguistic, emotional and cultural references or social attitudes (McRae, 1997).

Similarly when English is taught as a specialized subject it traditionally follows the cultural model of literature teaching which is absolutely teachercentred and lecture-based. The traditional literature classrooms emphasize product-based teaching and students are expected to write interpretations of texts using literary theory; background reading on age, movement; and genre. The selected texts in the Literature curriculum are remote to learners' experience and lack activities based on the literary language and so learners' basic linguistic skills do not improve much. The relatively new emphasis on Applied Linguistics and ELT curriculum does not have extensive literary reading materials and learners are not exposed to authentic English. Literature is often considered difficult and 'not a practical' subject of study as it does not foster any skill. Applied Linguistics and ELT also lead to product-based teaching where students are expected to come up with linguistic interpretations of language and develop linguistic concepts and ideas which encourage memorization. Learners' language skills remain inadequate here as well. A huge gap between language and literature has been created this way in our English Departments and students' English is deteriorating increasingly. In EFL or ESL contexts, (Literature/ Applied Linguistics and ELT), the main purpose of teaching English at tertiary level should bedeveloping basic language skills along with acquiring knowledge on the subject. My hypothesis is by selecting appropriate 'representational materials' and literature with a small ' 1 ', devising language-based activities, and integrating language with literature our English classes may be enhanced.

\section{LITERATURE REVIEW}

In Bangladesh, not much research on teaching language through literature has been conducted. Only recently has it begun to get some significance. Shahidullah (1991) focuses on the potentials of teaching literary pieces to develop English skills. His lesson plan and class activities on the poem "Crabbed Age and Youth" by William Shakespeare are prepared for Foundation Course (FC) language students. The activities made are not aided to involve students of English Major (EM) for critical analysis or cultivating interpretative ability on specific linguistic features of the literary text. He points out how literature as resource material can facilitate language use. However, he does not provide learners with any tool or checklist for developing critical appreciation of form and content, themes and techniques. 
Nonetheless, he gives importance on appropriate selection of graded texts, lesson plan at several stages and task-based CLT for especially promoting language skills. His paper is based on Collie and Slater (1999), and Tomlinson (1986) who demonstrate how communicative approach with theme oriented literary piece can stimulate learners to engage themselves at successive stages and come up with their personal responses. He terms literature as 'authentic' which is genuine, original and undistorted and not prepared artificially for language teaching purpose. He also highlights that if literature is used vis-à-vis with other materials that we come across in our daily life-like, travel timetables, city plans, application forms, pamphlets, cartoons, songs, advertisements, newspaper or magazine articles will be effective. He says literature is useful for EFL/ESL because they learn to "...cope with language intended for native speakers and thus they gain additional familiarity with many different linguistic uses, forms and conventions of the written mode: with irony, exposition, argument, narration and so on."

Khan (1999) discusses specific problems of learners in Bangladesh context by using literature in the language classroom and gives an example of a detailed lesson plan at various stages with worksheets to be used in class to cope with Thomas Hardy's novel Tess of the D'Urberville. Incase of linguistic difficulty of our learners, she points out syntactic complexity, lexical density, phonology and discoursal organization. She also talks of other typical problems of Bangladeshi students, such as - the length of literary pieces which often come in bulks of reading. The cultural difficulties our learners face, as she points out, are the range of allusions or references, conceptual and acceptance difficulties. However, I found her text selection somewhat impractical because Hardy's text can never be taught in full length in a language class, and only EM students are required to adopt individual critical analysis of the content, form and language of the text. She does not aidstudents with any stylistic tool or any theoretical stance for developing learners' interpreting ability that this particular text may be required to be taught at an advanced English class.

Alam (2007) in his long literature review of ELT, critiques the Western ELT experts' ready made formula for EFL/ESL learners to justify the usefulness of using literature 'their way' (from the Western perspective) and their constant changing of teaching methods, e.g. from Grammar-Translation method (which proved effective during our pre-liberation period) to the present day CLT approach(now a catch word in language teaching). Although he mainly speaks for secondary and higher secondary levels, he does not specifically mention teaching approach of tertiary level. His paper points towards a very important issue of using South Asian Literature in English or Translations which are more relevant to our students' experience. $\mathrm{He}$ also provides an interesting list of literatures written in English from 
Bangladesh and West Bengal and how they can be exploited in the English classes.

In a joint essay by Yeasmin, Azad and Ferdoush (2011) the need to introduce literature in the EFL language classroom has been aptly emphasized, based on a case study on the project "Readers' Development Program" by the British Council, Bangladesh, executed in the Department of English at ASA University. The program was launched in 2010 on first semester students taking English as a mandatory language requirement enrolled in BBA, Law, Pharmacy and Sociology to develop their language skills with abridged and graded materials from Macmillan Readers series, like - Heidi, The Woman in Black, Far from the Madding Crowd and The Mark of Zorro. This project was carried out for only FC students and not for EM students. The activities prescribed were language-based that fit with the syllabus of the course.

However, I found these texts very Eurocentric and unauthentic, as they are retold, abridged versions of original texts and linguistic imperialism imposed by the British Council in the name of language teaching. The principle reason for using literature is to teach authentic material teaching native-like English to EFL learners. In this respect the texts that were used in this experimental project were inappropriate. Literature with a small ' 1 ' could have been more useful in Bangladeshi context.

\section{ADVANTAGES OF USING LITERARY TEXTS}

\section{Motivating Material}

In many cultures, literature is considered a motivating material, and Bangladeshi students are culturally aware of this fact of improving language through extensive literary reading. Since most Bangladeshi students have studied literature to improve language in schools and colleges in their mother tongue, they will find studying literature in English interesting and thoughtprovoking. Introducing literature in the language class should not be difficult, although some students may always view literature as eye-browraising. However, like Chomsky's notion of 'grammatical competence' Culler has argued of learners' implicit quality of 'literary competence' (Lazar, 2005). Therefore literature should be a valuable and stimulating material for our students, especially for FC students. EM students go through extensive reading of many life changing diversified texts that motivates them in critical thinking and improves their interpretative abilities. However, in order to make them more aware of creative language use, text selection must be done carefully and teaching strategies for EM students should be language-based which is often ignored in our literature classes. 


\section{Expands Language Awareness}

In literary texts, we find a wide range of authentic use of language, style and registers. A common argument against using literature in the language classroom is, literature uses deviant language and the question is whether to use or not to use literature for language teaching. Nevertheless the potential of using literature in language class is unlimited. Literature in language has immense possibilities to teach various kinds of language, as the language of literature breaks the usual rules of syntax, collocation and cohesion. Widdowson (1986) says, by exploring sophisticated language of literature learners are encouraged to think about the norms of language use, specific stylistic effects and also "how this is achieved by departing from a norm" (Lazar, 2005). So both FC and EM teachers should select 'representational texts' that expose all kinds of languages ranging from canonical to Avantgarde, literatures from main-stream to alternative writing, translations, advertisements, memoir, travel writing, fiction and non-fiction, lyrics or any literature with a small 'l' from as many different genres of English writing as

possible. Varieties of English can expand our learners' knowledge of different styles, genres, registers, dialects and array of global English variants.

\section{Encourages Language Acquisition}

In the rural areas where students have limited access to spoken English in Bangladesh, literary reading materials can encourage language acquisition by successful promotion of students' language activities. Through groupwork or discussion students can share their feelings and opinions on literary texts that carry multiple layers of meanings. For example, role play of a drama extract or recitation of a poem may help students to "internalize vocabulary, grammar patterns or even intonation." (Lazar, 2005) Playreading or play-acting and recitation will encourage students to improve their verbal communication skills and motivate them to learn English with fun and enjoyment in an effective way.

\section{Develops Interpretative Abilities}

According to Widdowson (1986), literature is a good source for developing students' abilities to infer meaning and make interpretations because literary texts are rich in meaning that demand learners' active involvement in understanding the implied meaning. There is no 'wrong' or 'right' answer in literature; so it encourages learners of FC to come up with their personal interpretation. If EM students are aided by guided reading material or analyzing tool or checklist they will be able to critically interpret or analyze the language of the text more systematically on their own. 


\section{Window to Cultural Background}

Cultural Studies has now become an important focus in English Departments and culture is inter-connected with language. In order to get to know a culture one must study the language of their literature. According to Carter, such process-based language awareness can also be a point of entry for learners into cultural awareness, both with a small 'c' and a large ' $C$ ' (1999). Or to put it another way, in order to learn the language of a culture one should study its literature and the specialized study of literature should teach students to come up with critical reading of the underlying culture and ideological assumptions of a literary text. This way of reading literature from a process-based approach will also reduce the tendency of a product-based learning condition of our English classes and stop learners from memorizing answers for exam. English can thus become a window for our learners to know various cultures of the world.

\section{Instills Humane Qualities}

Apart from linguistic benefits, literature has a wider function of educating the learners at large by stimulating their imagination, developing critical thinking abilities and increasing emotional awareness. By becoming confident, sophisticated and empowered to use the language, students learn to relate the values and traditions of their own culture with that of the literary texts. Besides, by reading World Literature in English our learners can become citizens of the world.

\section{METHOD}

The objective of this research is to explore the possibilities, problems and solutions of using literature to FC and EM students at undergraduate level. It is thus expected that this empirical research will directly connect us with the actual condition of our language class for implications on how literary resources can be exploited. I conducted the survey in 2012 on approximately ten private and public universities, twenty English teachers and two hundred students at random under four different sets of survey questionnaires from the capital city, Dhaka.

The first group included teachers teaching English language in FC programs and students who had taken English as a mandatory language requirement. The language curriculum and sample test questions were also collected for determining drawbacks in text selection and language testing. The other group of questionnaire included teachers teaching English as a specialized subject (Literature /Applied Linguistics and ELT) and students of EM to survey the teaching and learning condition of English Departments in Dhaka. 
In this case, the curriculum and sample test questions were also surveyed to observe the level of linguistic competence of EM students.

I made four detailed and separate set of questionnaires. For FC students, I deliberately kept the language of my questionnaire general and less technical - with more MCQs, mostly yes/no questions and a very few open ended questions (Appendix A) . The questionnaire for the language teachers at the tertiary level was elicited to support the objective of this research and included more open ended questions, some MCQs, a few yes/no questions and involved a more technical stance (Appendix B). The third round of questions set for the students of English Departments were written in a more technical language with which they were supposed to be familiar with; yet I included more MCQs and yes/no questions (Appendix C). On the other hand, questionnaire for the teachers of EM who teach English Literature/Applied Linguistics and ELT were more detailed and open-ended with a few yes/no and MCQs, in the view that the study would both expose shortcomings and also suggest solutions (Appendix D). Data collected from all these respondents had been categorized and provided by percentage in different graphs to derive at qualitative analyses from the results.

\section{Limitations}

Due to time and related social constraints, I was not able to survey more samples. I realize the results of my survey could have been more convincing if I could survey respondents from other institutions such as BUET (Bangladesh University of Engineering and Technology), IBA (Institute of Business Institute) and DMC (Dhaka Medical College) where English is a mandatory requirement. Since I did not have enough time to interview samples in person, some interviewees were not familiar with words like 'authentic English', 'language-based approach', 'extensive / intensive reading', literature with a small ' 1 ', 'referential and representational' materials and product and process-based teaching and so their responses may appear somewhat unconvincing. Some teachers did not respond to all the survey questions, especially who are not informed of recent techniques or experimental teaching methods of literature. If I had more teachers interviewed, this research could have had better outcomes, and the importance of language teaching through literature would have been better informed. Additionally this paper could have in depth analysis if I had the chance to interview English experts from Bangladesh to backup my study. Direct classroom observation would have been also insightful, especially if I could make samplings of some case studies of experimental teaching, text selections, work-sheets and activities with lesson plan and exam questions with South Asian/ Bangladeshi English texts/ translations of Bangla literature which I did but in small scale. 
8| ELT Worldwide Vol. 2 No. 2 October 2015

\section{FINDINGS AND ANALYSES}

I have categorized the survey results under two areas and focused on some highlights of my findings so that we could arrive at some insightful implications for enhancing our English classrooms.

\section{Insight on Syllabus \& Curriculum}

This study clearly brings out the necessity of literature in the development of language. More than 73\% FC and EM students think that literature can improve their quality of English. On the other hand, 70\% FC teachers and $80 \%$ EM teachers think that literary texts can enhance the linguistic competence of our learners. This result also positively suggests that Bangladeshi students are quite motivated to learn English. So this statistics shows that, including literature as resource material in the FC curriculum and selecting relevant literary texts in the EM curriculum and introducing language-based teaching approaches may be welcomed by teachers and learners in our classrooms.

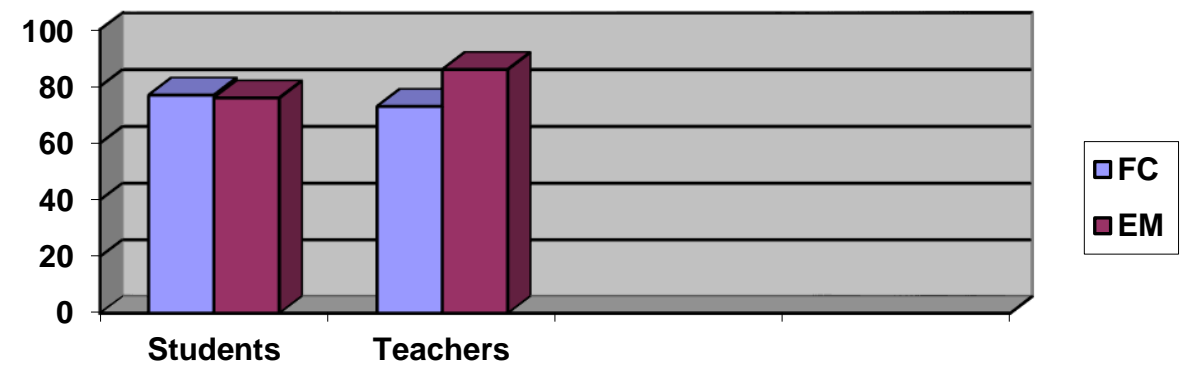

\section{figure1:literature enhances language acquisition}

In relation to this, it was also found 5\% FC students and 50\% EM students want literature in their curriculum relevant to their experience, be it translation or literature in English from other parts of the world. More EM students are aware of this probably due to their understanding of its importance as they have been specializing in this subject. 60\% FC teachers and $80 \%$ EM teachers feel that instead of including only English Literature, that is culturally remote to their experience, literature syllabus must be selected from a wide range of translations of local or South Asian Literature in English. 


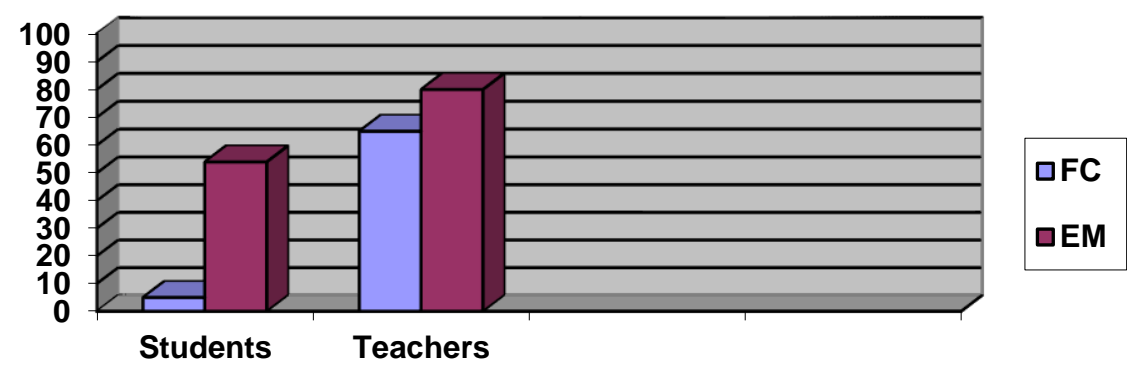

\section{figure2: English syllabus must include relevant literature in English}

One contradictory result of the finding is that, most students and teachers do not think the traditional language syllabus is boring. Only 30\% students and $33 \%$ teachers in the FC class think that it is demotivating. This is an indicator that they have become 'fossilized' with the system of the Grammar-Translation method and the CLT approach of language teaching and are not familiar with the concept how language classes can be made more fun-oriented and effective if literary texts, or 'representational material' are included and taught with the appropriate combination of different approaches. The result also indicates that teachers too have become accustomed to the traditional teaching. However this statistics also indicates no matter how demotivating language classes are, learners and teachers are positively motivated to learn and teach English.

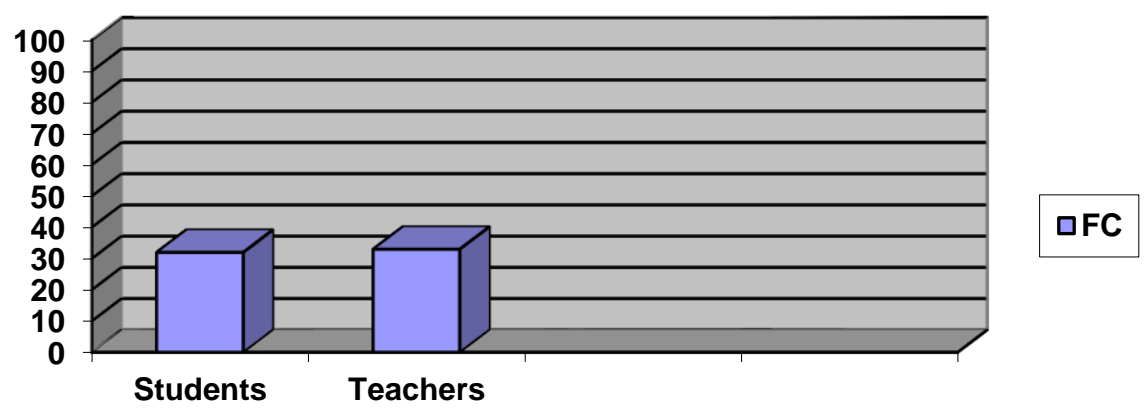

\section{figure3:traditional language syllabus is boring}

More than $40 \%$ FC teachers feel that language syllabus must contain authentic texts in English with literary language or texts that contain literary 
linguistic features so that learners may benefit themselves by using language in an innovative way.

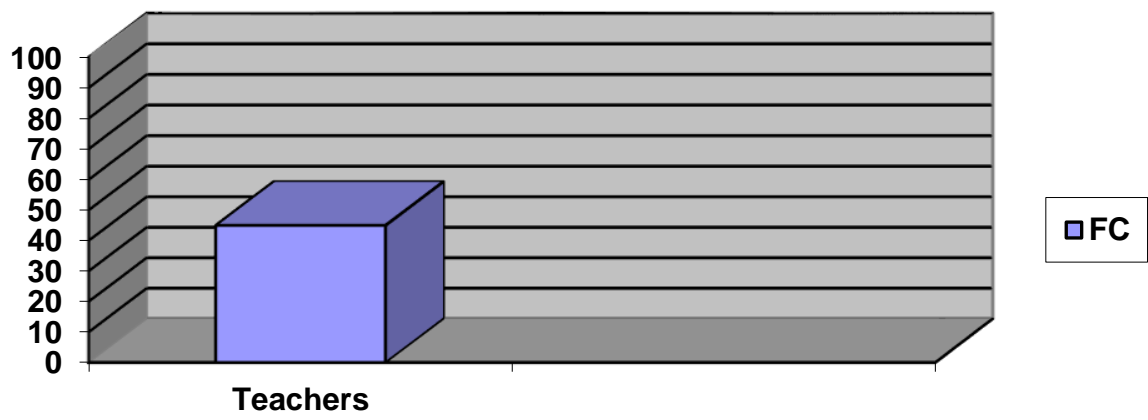

figure4:language syllabus must contain authentic English texts

\section{Findings on Teaching Approach}

More than 40\% FC teachers think that our language classshould be more language-based, task- oriented and less teacher-centered or lecturebased.This implies that $60 \%$ teachers are opposed to this approach of teaching English and feel more comfortable lecturing and in teacher-centered classrooms. This also indicates that some teachers believe in combining different approaches of teaching or might be still conducting language classes by lectures only.

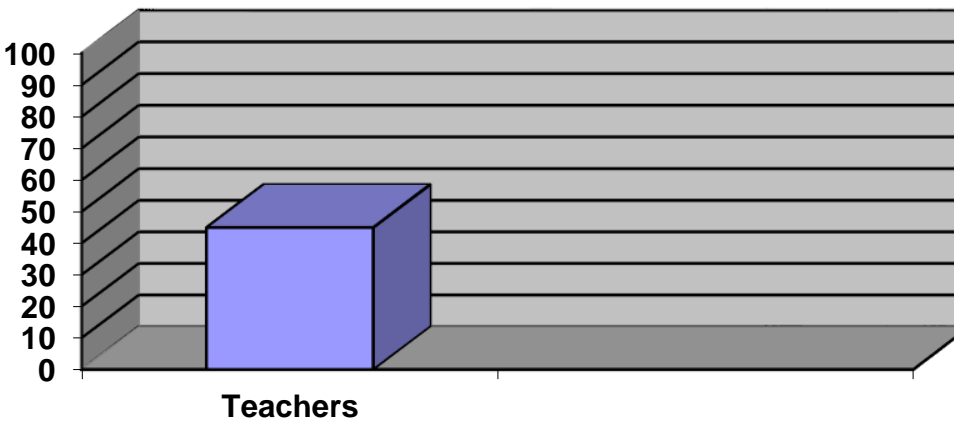

figure5:uses language based approach in the language class

Similar to this, another loophole has been pinpointed that there is a discrepancy between FC and EM teachers in terms of lesson planning. Only 40\% FC teachers and 98\% EM teachers follow lesson plans. This clearly indicates FC teachers are not putting the right amount of effort in their 
classroom teaching. On the contrary, EM teachers are clearly pressurized to complete their syllabuses on time both at public and private universitiesespecially in private universities where they have tri-annual semester system. However, only lesson planning in the class does not indicate that other classroom procedures such as language-based activities on the literary texts, process-based teaching, and combination of extensive and intensive reading practices are carried out proportionately. This practice of language teaching could reduce the pressure of both FC and EM teachers and learners and encourage learners for close reading and language-based activities.

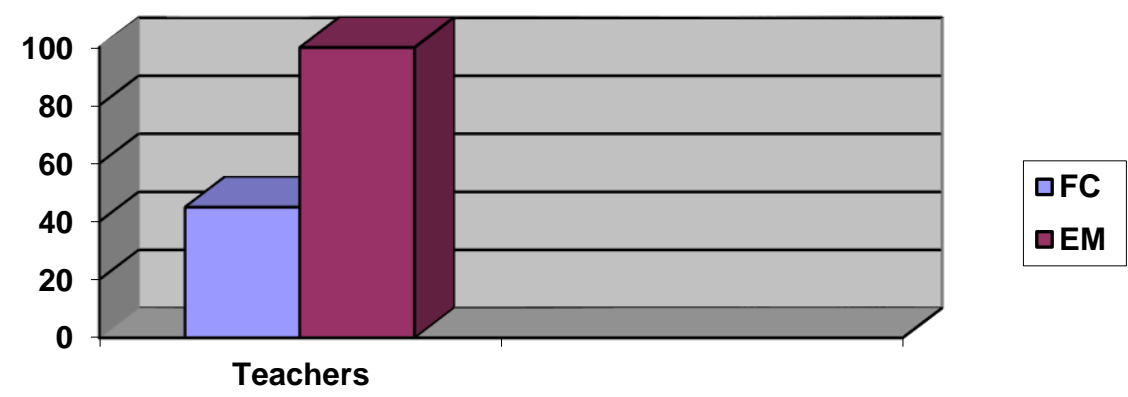

\section{figure6: usage of lesson plan}

23\% students and $70 \%$ teachers of EM programs suggest that the English Department curriculum must be relevant to learners' experience, based on their needs and should be a combination of different approaches like, language-based approach, literature as content and literature for personal enrichment. It is also a positive finding to notice that teachers, more than students, feel the need to assimilate new ways to make classroom teaching more effective. Thus, teachers of both FC and EM need to become creative to ensure language enhancement.

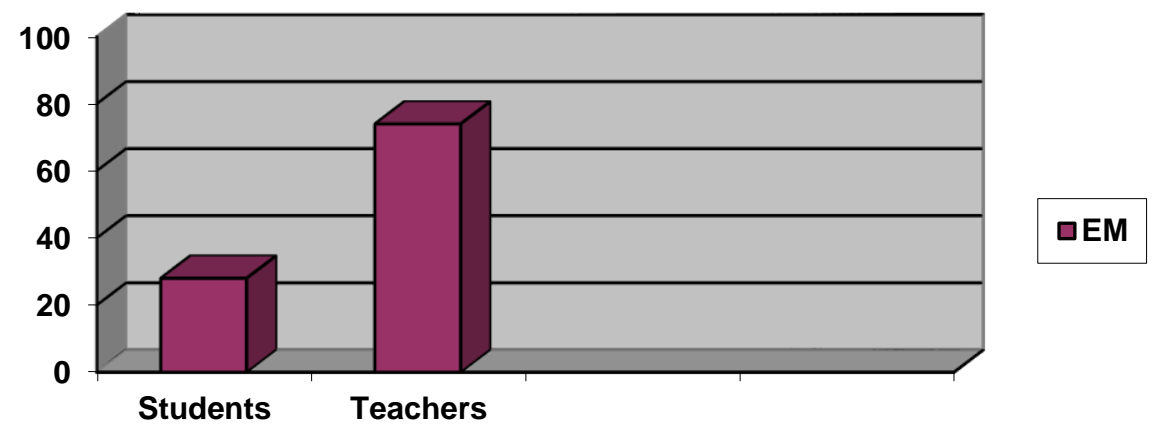

figure7:English classes should a combination of different approaches and relevant to the student's experience 
More students than teachers in the EM program are interested to use stylistics as a tool for interpreting literature. EM teachers think that stylistics can provide learners with a systematic method to read a difficult subject like literature.50\% teachers and $75 \%$ learners feel that including stylistics in their syllabus will increase learners' linguistic and literary competence. The reason why teachers are less encouraged is because they are aware of the effort they have to give in class to devise tasks and activities and make work-sheets on stylistics in order to build up learners' linguistic and literary competence. They are still used to lecture-based classes and not aware of process-based teaching Literature as a specialized subject that can engage learners in critical analysis.

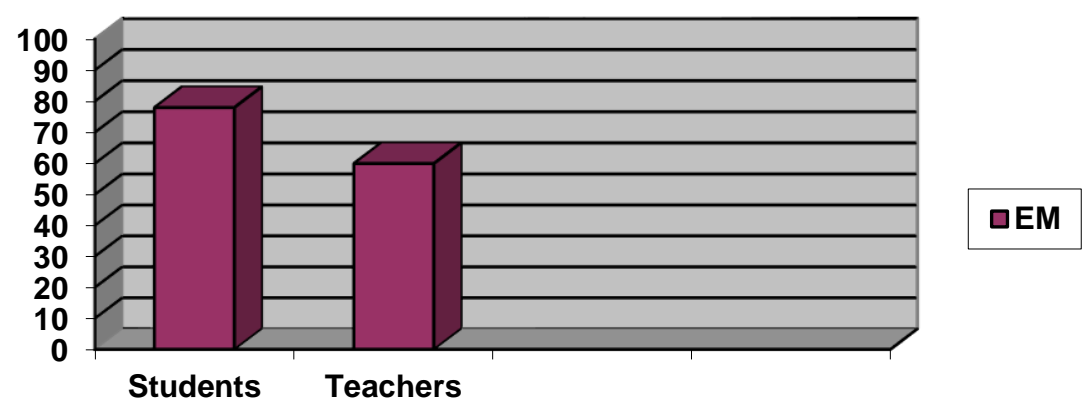

figure8:stylistics develops both literary and linguistic competence

\section{Other Highlights}

One of the most important findings of my research is, both teachers and students agree that the principle reason for studying English (for both FC and EM students) should be to learn basic language skills. Literary Theory can serve an interesting apparatus for interpreting literary texts to increase that critical thinking but language development must be of fundamental importance. 90\% students and lesser teachers (50\%) think they need to develop their language skills first. This result also indicates how most English Departments in Bangladesh are deviating from their primary purpose of language teaching in the EFL context. Both L1 and L2 students must be aware of learning the language of literature properly by close reading. 


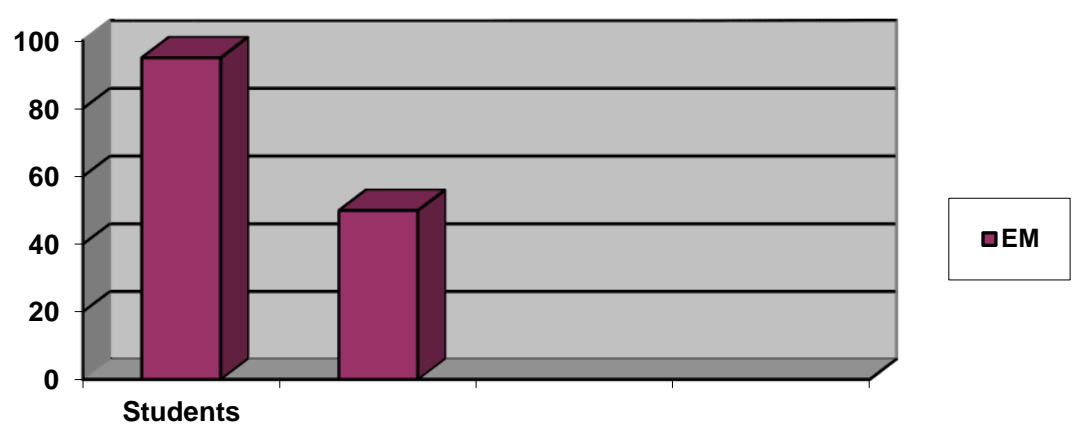

figure9: the primary reason for learning English is to use the language accurately

According to the findings, both students and teachers think Literature difficult. About 62\% FC and 92\% EM students deem Literature as a tough subject. In Bangladesh, learners are more used to subjects that require memorization and less creativity. English Literature requires a lot of creativity both from teachers' and learners' perspective. Teachers find it more challenging to teach literature at both FC and EM programs. 40\% FC teachers and $80 \%$ EM teachers see literature teaching as a daunting task. Interestingly, more EM teachers and students find literature difficult than FC teachers and students. The survey also revealed that many teachers are not familiar with the concept of 'referential texts', 'representational texts' or literature with a small ' 1 '. This indicates both EM and FC teachers' need to be trained particularly on how literary texts may be taught with different focus by selecting texts that are culturally sensitized or relevant to our context.

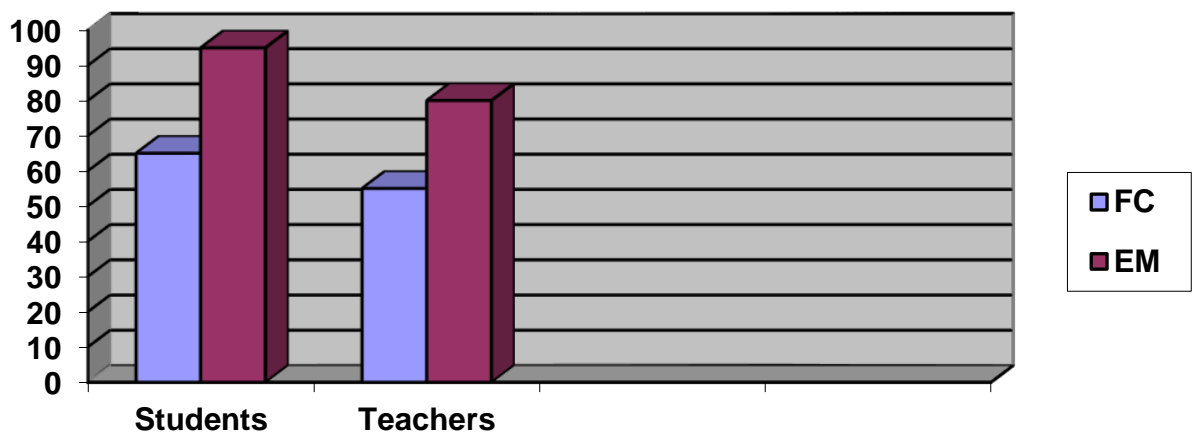

figure10: literature is difficult 
Another striking result of this study is, 50\% teachers and50\% students of EM program agree that despite majoring in English, students lack general linguistic competence; $23 \%$ students and 36\% teachers of FC class think that students of English Department do not have adequate language skills. This clearly points out the poor performance of our learners and teachers as well.

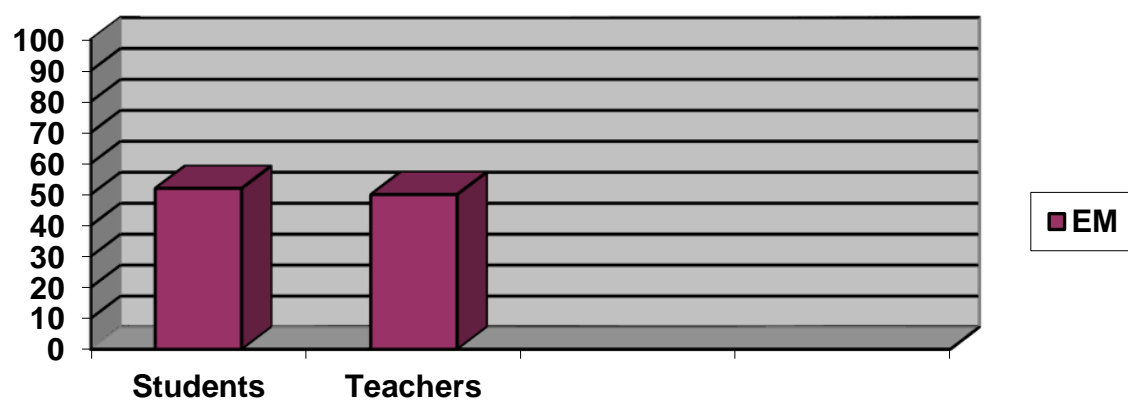

figure11:English majors also lack linguistic competence

\section{RECOMMENDATIONS}

From the research findings and reading of ELT experts-such as, McRae, Carter, Short, Lazar and Long-I have suggested some ways to combat some of our specific problems. Choosing relevant texts, combining teaching approaches lesson planning with lecture and students' activities, and changing the evaluation system and testing apparatus, we can improve our teaching condition.

\section{Text Selections}

According to Lazar, text selection mainly depends on the level of students and the focus of the course and also some other factors such as - availability, length, exploitability and the syllabus (2005). McRae suggests language teachers may use materials with imaginative content that stimulates the reaction and response of the receiver, termed as the 'representational' texts. In second language learning and teaching context literature has usually tended to have a capital ' $L$ ' that intimidates the learning condition and so he suggests literature to be used with a small ' $l$ ' for language development. Literature considered with a small ' 1 ' can be any kind of material with imaginative or fictional content that goes beyond the purely referential, and "brings imaginative interaction, reaction and response into play" (1997). Lazar (1993) emphasis the fact that any text may be included ranging from 
weather forecast to daily conversation, advertisement to pop songs, cartoon to travelogue that contains literary language. He uses this scale to choose relevant texts for students:

\begin{tabular}{|l|ll|}
\hline & \multicolumn{3}{c|}{ Students' Cultural Background } \\
too remote from & A & close enough to \\
text to help & text for easy \\
comprehension & comprehension \\
\hline
\end{tabular}

\section{Type of Students}

Texts should be selected and graded according to the students' linguistic proficiency; student's age, emotional understanding and intellectual maturity; interests; and cultural/ethnic and literary background. In relation to this, Hill (1998) emphasizes how literature provides a genuine context and motivates learners to internalize their experience. By looking at various problems of teaching literature-like difficulty of grading texts-the problem of aiding learners with a linguistic model for individual analysis and the complexity of choosing relevant text, she adopts various means to teach full length texts by devising tasks on content, character, structure, style and purpose. According to her literature provides a wide range of language contexts and so learners can grasp the communicative functions of language.

\section{Type of Course}

The main focus of FC course is developing basic language skills. So selections may be made from literary texts such as-non canonical texts, translations of Bangla literature or South Asian literature in English. However, once in a while English texts by native or foreign writers may be included for engaging students in creative linguistic activities sometimes aided by teachers' notes/ glosses to help learners with cultural ambiguities. But Carter and Long recommends literature not to be considered as a sacrosanct but to be used in the language class with any other authentic text that consists of literary languages (1991).

In EFL/ESL context like Bangladesh, heavy hitters and full-length texts such as Shakespeare, Milton and Chaucer may be avoided for EM students and replaced by extracts for beginners. For FC students, only anonymous literary extracts by modernist writers may be selected. The syllabus of EM students may be thematically selected from various sources to bring diversity and globalism to the curriculum, yet remain connected to our learners' 
experience. Relevant texts from Sub-continent should be included along with Bangladeshi Literature in translation and other World Literatures in English. Here is a sample list of texts that can be taught at FC and EM courses:

\begin{tabular}{|c|l|l|l|}
\hline & Possible Texts for FC Students & & $\begin{array}{l}\text { Sample Texts for an Introductory Course } \\
\text { for EM Students (thematically selected on } \\
\text { war) }\end{array}$ \\
\hline 1. & $\begin{array}{l}\text { Song (Heal the World } \\
\text { By Michael Jackson) }\end{array}$ & 1. & $\begin{array}{l}\text { Novel extracts from ( Song of Our } \\
\text { Swampland by Manzu Islam) }\end{array}$ \\
\hline 2. & $\begin{array}{l}\text { Poem ( The Wall by Abdul Ghafar } \\
\text { Ibrahim) }\end{array}$ & 2. & $\begin{array}{l}\text { Translated short story from Bangla } \\
\text { ('Fugitive Colours" by Selina Hossain) }\end{array}$ \\
\hline 3. & $\begin{array}{l}\text { Play extract ( The Zoo Story by } \\
\text { Edward Albee) }\end{array}$ & 3. & $\begin{array}{l}\text { Bangladeshi English Poems ( 'Bangladesh } \\
\text { 71' and 'Getting it Right' by Kaiser Haq) }\end{array}$ \\
\hline 4. & $\begin{array}{l}\text { Tourism Slogans from Around the } \\
\text { World }\end{array}$ & 4. & $\begin{array}{l}\text { Play ( Arms and the Man by George } \\
\text { Bernard Shaw) }\end{array}$ \\
\hline 5. & $\begin{array}{l}\text { Novel extract ( A House for Mr. } \\
\text { Biswas by V. S. Naipaul) }\end{array}$ & 5. & $\begin{array}{l}\text { Modern English poems ('Requiem for the } \\
\text { Croppies' by Seamus Heaney, 'MCMXIV' } \\
\text { by Philip Larkin and 'Bayonet Charge' by } \\
\text { Ted Hughes }\end{array}$ \\
\hline 6. & Creative Advertisement texts & 6. & $\begin{array}{l}\text { Birangona Poems ( Birangona: Brave } \\
\text { Women) by Tarfia Faizullah }\end{array}$ \\
\hline
\end{tabular}

\section{Teaching Approaches}

Carter and Long (1991) speak of three different kinds of models of teaching literature: cultural model, language model and the personal growth model. FC class usually follows the language model and our EM class follows the cultural model and to some extent, the personal growth model too. After careful selection of texts for both FC and EM programs, we need to change our teaching approaches. Lazar points out three categories of teaching approaches - language-based approach, literature as content and literature as personal enrichment. Her detailed analyses of these approaches reveal that our FC programs are language-based but the selected texts are not 'representational'; hence we need to incorporate literature in the syllabus to motivate students into creative language activities to make them more language aware. In this way, FC classes will become less teacher-centered, more activity- and process-oriented and less product-oriented.

Our EM programs are not language-based. Teachers may have a better result if they can engage students into language activities based on the literary texts. They may only lecture to complement students' overall understanding of the text. Lack of language-based activities in the literary class is widening the gap between learners' language and literature competence. Teachers may aid students by providing analytical tool, checklists and guided reading materials and which will discourage students to memorize answers. 
According to McRae and Vethamani, language teaching should be influenced by the focus of the course, socio-cultural context and needs of the students. He recommends teachers to be always creative to motivate learners' imagination and make English teaching more effective. They provided a simple stylistic tool for EM learners to interpret texts by themselves. Lazar and Short have also devised checklists for aiding students with individual analysis of the language of literary texts.

Both McRae and Carter think that literary theory, particularly feminist theory and postcolonial theory, are of relevance to many EFL/ESL contexts which can also aid students to come with interesting interpretations. So aiding our EM students with a bit of theory can be rewarding. However, McRae (1997)highlights, “...the discussion of critical approaches should never be allowed to drown out the claims made to each individual by the object of all this attention: the text itself." So, he reminds us that at ESL/EFL context out primary concern should be to make our learners first linguistically competent. Once they have overcome linguistic barriers, literary competence will fall in its place and EM learners will develop their individual responses to literary texts using these aides. Developing teaching approaches include the following suggestions.

\section{Language-based Approach}

FC course teaching should adopt language-based approach since the focus of this kind of class is to enhance language competence. On the other hand, the focus in EM class is both language and literary competence, so it is recommended for a balanced combination of language-based approach, literature as content and also personal enrichment approach. Example to some language-based activities are given below.

\section{Activity-oriented}

By devising wide range of various kinds of tasks students can be motivated, for example- pyramid discussion, vote a quote, predictions, matching, jigsaw, grids and charts, cloze, gap filling, rewriting, creative writing, etc. For EM class teachers may also devise tasks on: analyzing metaphor, trope and figurative language, guided writing, rewriting viewpoints, elementary stylistics, role play, play-reading, drama performance, debate, developing a battery of topics etc. Teachers may aid students with a toolkit for analysis. For example the following poems can be taught at FC and EM classes: 


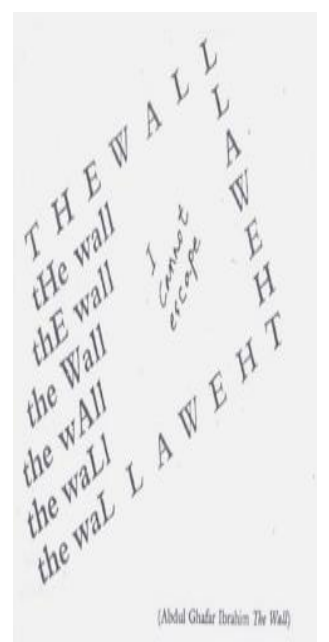

\begin{tabular}{|l|l|}
\hline \multicolumn{2}{|c|}{ Stylistic tool by McRae (1999) } \\
\hline Lexis & The words \\
\hline Syntax & The way the words are put together \\
\hline Cohesion & The system of links through a text \\
\hline $\begin{array}{l}\text { Grapholog } \\
\text { y }\end{array}$ & The look of the text, punctuation, layout \\
\hline Phonology & The sounds of the text \\
\hline Semantics & The study of meaning and how meaning is achieved \\
\hline Dialect & $\begin{array}{l}\text { Language as it is spoken, reflecting local and social } \\
\text { conditions }\end{array}$ \\
\hline Register & The tone of the text \\
\hline Period & $\begin{array}{l}\text { Modern or older; and the inter-textual influences on } \\
\text { the text }\end{array}$ \\
\hline Function & What the text does, the effect it has on the reader \\
\hline style & $\begin{array}{l}\text { The combination of all these elements in any single } \\
\text { text }\end{array}$ \\
\hline
\end{tabular}

'The Wall' by Abdul Ghafar Ibrahim (While-reading Activities For FC class)*

1. Do you think this is a poem?

2. Would it be very different if 'No escape' was written instead of 'I cannot escape' in the middle of the poem?

3. Is the text positive or negative in your opinion?

4. Is it a poem about keeping someone in or keeping someone out?

5. Is it a real wall? What could the wall be, in your interpretations?

6. Who do you think is the ' $\mathrm{I}$ ' in the poem?

7. Analyze the poem with the basic stylistic tool provided below.

8. Now write your own poem. 'House-wife', a poem by a foreign student of English is provided below as an example*.

*(this text was collected from Now Read On by McRae \&Vethamani)

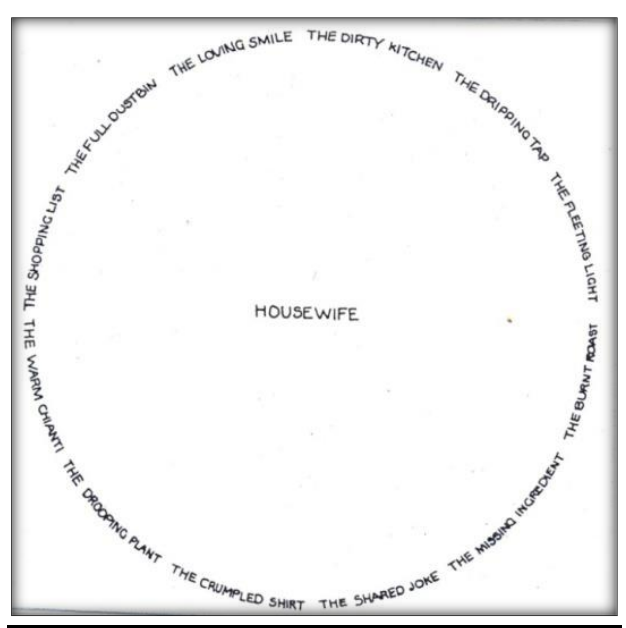

*This poem, written by a foreign student of English has been collected from The Web of Words.
Bangladesh ' 71 '

By Kaiser Haq

Venturing at last to go out

I blink at the guilt in the eye

And fumble with the throat

As if it were a tie.

Smoky dusk falls like fear

Over stone and human heart.

How, and with what, shall one create art?

Flames, death, then ash consumes the fire.

Blood of the doomed stains our sleep,

Like a question hangs pen over paper,

Fumbling fingers miss flesh they look for,

My love is vapour, but I don't weep.

Dawn stirs like a mouse; whose knock is it on the door?

*(from Published in the Streets of Dhaka by Kaiser Haq) 


\section{Class activities for EM Students}

1. Why do you think the man is fumbling with fear?

2. What metaphors does the poet use to create the fearful ambience of the poem?

3. Who do you think is knocking at the door?

4. Why do you think the poet is anxious about his creation?

5. Write a critical appreciation of the poem with the stylistic tool provided above.

6. Compare the similes and metaphors of war in this poem with other war poems in this course.

\section{Process-based Vs. Product-based Teaching and Learning}

It is important that we turn towards a teaching that is a process-based teaching and move away from product-based teaching. By solely lecturing, teachers are in danger of imposing their personal interpretation on students.

So if the class is designed according to a lesson plan where the teacher combines class- activities on the text and some lectures or discussions to complement the lessons then the students may go through a process-based learning and this way they can come up with creative interpretation of the text. In a class where the teacher leaves no scope for students to interact or involve in activities, students go for memorization or rote learning which is purely product-based learning. English teachers must opt for a Process-based teaching so that students' creativity in language learning is taken seriously and in the process learn to use language creatively.

\section{Guided Reading}

FC courses must be student-centered, task-based and process-oriented. On the other hand, EM classes should be less lecture-oriented, more studentcentered, task-based and process-oriented. To supplement short lectures for the EM students, teachers can provide short gloss, handouts, slide show on the projector and mini audio/visuals. Carter spoke about stylistics both positively and negatively on leaner's use of stylistics, stylistics may be included only if the ESL/EFL condition permits (1999). However both McRae and Carter think there should be some reservation about providing aids to students. Sometimes teachers can allow students' imagination to reign. Background reading or information may be given after students turn up with their own analysis of the text. The check list below was provided by Lazar for analyzing poetry. Simpson (2001) explored how poetry could be 
analyzed from graphological and morphological perspective for increasing linguistic awareness of students. He also discussed how discourse analysis can be useful in teaching the language of drama for advanced students of English. Similarly patterns of cohesion and lexical semantics can be introduced to study the language of fiction. Geoffrey Leech $(2007,2014)$, Mick Short (2014) and Michael Toolan (2001) have written a number of interesting books where they have introduced basic linguistics to teach the language of literature. However, inspite of the advantages of teaching stylistics to EFL/ESL students, Gower (1986) and Carter (1999) are apprehensive about including stylistics to non native learners. Unless they are familiar with the system, teachers of EFL/ESL need to be cautious about stylistics and only used in combination with other strategies.

\begin{tabular}{|l|l|}
\hline \multicolumn{2}{|c|}{ A checklist for meta-language of Poetry by Lazar (2005) } \\
\hline Metaphor & $\begin{array}{l}\text { A comparison made between things which are unlike each } \\
\text { other by describing one as if it were the other. }\end{array}$ \\
\hline Simile & $\begin{array}{l}\text { An explicit comparison made between unlike things which } \\
\text { is usually indicated by using the words like or as. }\end{array}$ \\
\hline Personification & $\begin{array}{l}\text { A kind of metaphor in which abstract or animate objects } \\
\text { are described as if they were alive and animate }\end{array}$ \\
\hline Paradox & $\begin{array}{l}\text { A statement which appears to be contradictory or absurd, } \\
\text { but may be true }\end{array}$ \\
\hline Oxymoron & $\begin{array}{l}\text { A combination of neighbouring words which seem } \\
\text { apparently contradictory or incongruous }\end{array}$ \\
\hline Metonymy & $\begin{array}{l}\text { A figure of speech in which the name of a thing is } \\
\text { substituted for another thing which it is usually associated }\end{array}$ \\
\hline Synecdoche & $\begin{array}{l}\text { The whole of something is used to mean the part of it, or } \\
\text { part of it is used to mean the whole }\end{array}$ \\
\hline Apostrophe & $\begin{array}{l}\text { The direct addressing of an abstract quality, object or } \\
\text { absent person }\end{array}$ \\
\hline Alliteration & $\begin{array}{l}\text { The repetition of the initial constant sounds in two or more } \\
\text { consecutive words }\end{array}$ \\
\hline Assonance & $\begin{array}{l}\text { The repetition of identical or similar vowel sounds, usually } \\
\text { in the middle of words }\end{array}$ \\
\hline
\end{tabular}

\section{Lesson Plan}

Teachers at all levels should follow lesson plans not only monthly or weekly but also on daily basis. The stages of pre-reading, while-reading and followup activities must be meticulously observed to facilitate learners to develop language skills. Previously I have provided some other activities for FC and EM students to be used at while reading stage. CLT for the FC can play a useful role however at advanced stage it is better for teachers to let students 
work on their own and occasional intervention of teacher's lecture and discussion can fill in gaps of learning. The class activities must be devised in such a way that the EM students are guided to learn specific stylistic, linguistic and generic features of the text. For example, after the warm-up session, the following extract can be analyzed with the checklist provided in the while-reading stage of the lesson plan inorder to understand relationship and social status between characters:

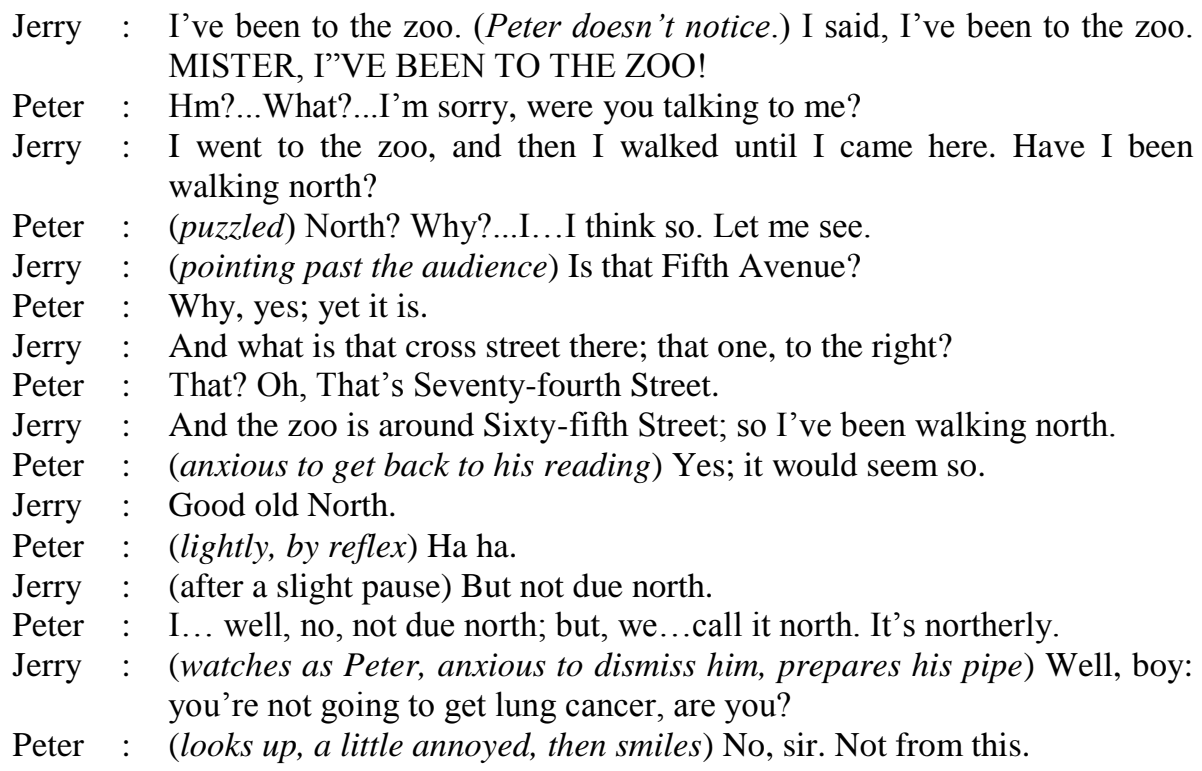

\begin{tabular}{|l|l|l|}
\hline \multicolumn{2}{|c|}{$\begin{array}{c}\text { Conversational Structure and Power Check-sheet for Play Texts by } \\
\text { Short (1989) }\end{array}$} \\
\hline CONVERSATIONAL BEHAVIOUR & $\begin{array}{c}\text { POWERFUL } \\
\text { PARTICIPANT }\end{array}$ & $\begin{array}{c}\text { POWERLESS } \\
\text { PARTICIPANT }\end{array}$ \\
\hline Who has most turns? & & \\
\hline Who has longest turns? & & \\
\hline Who interrupts whom? & & \\
\hline Who allocates turns to whom? & & \\
\hline Who initiates? & & \\
\hline Who responds? & & \\
\hline Who controls/changes the topic of talk? & & \\
\hline $\begin{array}{l}\text { What terms of address are used by one } \\
\text { character/person to another? }\end{array}$ & & \\
\hline $\begin{array}{l}\text { Other significant features e.g. } \\
\text { paralinguistic features, actions. }\end{array}$ & & \\
\hline
\end{tabular}




\section{Intensive/Extensive Activities}

FC and EM classes must be both careful about the combination of intensive (in depth) and extensive (wide breadth) reading on the level of the students and focus of the course. However in our context in FC class, teaching needs to have both these approaches equally and in EM class there should be more extensive reading. Classroom teaching should be dedicated mostly to tasks and discussing responses. Extensive reading followed by short assignment may be given for home tasks. Teachers must remember that there is a difference between literature as a resource material and specialized subject or discipline, and intensive and extensive activities must be provided according to the focus of the course. One loophole of teaching English class is, the length of class in most public universities is 50 minutes and class size on the average over 100 students; this makes it extremely difficult to conduct language-based activities and follow lesson plans. So teachers are often forced to lecture, without facilitating students activities. However, private universities and some public universities who have initiated with six month long semesters, 90 -minute classes with no more than 40 students may easily apply this approach of language teaching.

\section{Developing a Resource Pool}

Using resource books can provide a wide range of interesting literary texts and provide useful techniques for teaching but teachers can also select texts themselves and explore various ways of teaching. Our teachers must develop individual graded teaching resources so that students can culturally relate themselves with language teaching according to their maturity. Before they start selecting texts, teachers can use some of the resource books already available and keep developing their own bank or pool of interesting texts relevant to our student's cultural orientation. One good way to select materials would be to select them thematically, such as under war, love, mother, money, nature, fantasy etc. category.

\section{Training and Workshop}

Teachers at the tertiary level must go through workshops on how to select texts for both FC and EM courses and then learn to make different kinds of worksheets to be used for intensive class activities provided with extensive reading and writing follow up activities for advanced students of English. Teachers should become familiar with the idea of teaching the language of literature themselves first and then orient students with new strategies of reading literature. This is how they can become aware of the possibilities of studying language and creative use of language teaching. When English teachers come together for training or workshop for creative language 
teaching, they will be able to share ideas and experience for developing a new English curriculum with new teaching techniques.

\section{Evaluation and Testing Apparatus}

Evaluation of learners' language acquisition is an import part of teaching. Teachers should set questions from lower to higher order, from less difficult to more difficult questions. There should be more open-ended than closeended questions, so that students get the scope to engage in creative thinking. Insightful questions, more textual and specific than contextual and general questions will make students comprehend the text better. Teachers should avoid rigidity of setting traditional questions to stop rote learning and memorization of answers. Advanced questions for EM students should have an integration of language and literature in both exam situation and classroom condition.

Question that requires only memorization and 'information retrieval' should be avoided by all means for EM courses. Instead of setting general essay type questions on background, short innovative and specific questions on the text can be set. Comprehensions, translation and paraphrasing can enhance students' interpretation for both FC and EM students. For advanced EM students, questions can be set on implicit social / religious/ political features. In teaching poetry to EM students, poetic features like rhyme, sound patterns and tropes can be useful to develop linguistic competence. Teachers must avoid setting traditional questions and make learners see the texts as statements of faith, devotion, sincerity etc. Questions such as "Illustrate from the stories of how Lawrence's attitude to his characters is often a mixture of ridicule and compassion" should be avoided. Or specific questions like, "What is there in the scene in which Romeo and Juliet first meet that gives dramatic excitement?, "How are both situation and feelings of Romeo and Juliet made especially intense by particular words and phrases?" More questions on reference to the context of the text, e.g. "What are the themes in the following text, and how are they interrelated?" may be considered for examinations. Open-book examination term paper writing can also encourage EM students to stop writing memorized answers or plagiarize in term papers and teach them to make textual references in the essays.

\section{CONCLUSION}

My research outcome shows that literature has a lot of possibilities for better language teaching in Bangladesh. After many years, literature has started to return to the curriculum of schools and colleges as the CLT approach of 'referential texts' have failed completely. This altogether means, we must rethink of integrating language and literature at the tertiary level too. It is not 
students' lack of motivation rather our teachers' inability to choose appropriate texts with the right approach and class room activities that has hindered proper language acquisition. We have to move away from the traditional system of lecturing and develop our own teaching approaches and aid learners with appropriate strategies for reading literary texts by stimulating activities and fill-up the gap between language and literature as much as possible. Both the literature and linguistics experts should forget all disputes and join hands in building a bridge to improve the condition of our English classes at the tertiary level.

\section{REFERENCES}

Alam, F. (2007), Using Postcolonial Literature in ELT, Imperial Entanglements and Literature in English, Dhaka: writers.ink, 373390.

Brumfit, C.J. and Carter, R.A. (1987), Literature and Language Teaching, Oxford: Oxford University Press

Carter, R. and Long, M.N. (1991), Teaching Literature, Hong Kong: Longman Group (FE) Ltd.

Carter, R.A. and Long, M.N. (1996), The web of words: exploring literature through language, Cambridge: Cambridge University Press

Carter, R. and McRae, J. (1999), Language, Literature and the Learner, London: Longman

Collie, J. and Slater, S.(1999) Literature in the Language Classroom, Cambridge: Cambridge University Press

Hill, J. (1988), Using Literature in Language Teaching, London: Macmillan

Gower, R. (1986), Can stylistic analysis help EFL learner to read literature?ELT Journal, Oxford: Oxford University Press, Volume 40/2, pp. 125-130.

Khan, R. (1999), Literature in The Language Classroom: Some Solutions to Handling Thomas Hardy's Tess of the D'Urberville, The Dhaka University Studies, 43-58.

Lazar, G. (2005), Literature and Language Teaching, Cambridge: Cambridge University Press. 
Nusrat, Bridging the Gap Between Language and Literature $\mid 25$

Leech, G.N. (2014). A Linguistic Guide to English Poetry, London: Routledge

Leech, G.N. and Short, M. (2007), Style in Fiction: A Linguistic Introduction to English Fictional, London: Longman

McRae, J. and Boardman, R. (1989), Reading between the lines: integrated language and literature activities, Cambridge: Cambridge University Press

McRae, J.(1997), Literature with a small 'l', London: Prentice Hall ELT

McRae, J. and Vethamani, M.E., (1999), Now read on: a course in multicultural reading, London: Routledge

Shahidullah, M. (1991), The Use of Literature in Language Teaching, The Rajshahi University Studies, (Part A), 19:145-159.

Short, M. (1989), (ed.), The language of poetry: The application of literary stylistic theory in university teaching, Reading, Analysing and Teaching Literature, London: Longman, 241-266.

Simpson, P. (1992), Language through Literature: an introduction, London: Routledge

Tomlinson, B., (1986), Using Poetry with Mixed Ability Classes, English Teaching Forum, Vol. 40(1): 33-41.

Toolan, M. (2001) Language in Literature, London: Arnold

Widdowson, H.G. (1986), Stylistics and the Teaching of Literature, Hong Kong: Longman Group (EF) Ltd.

Yeasmin, N., Azad, M. A. K. and Ferdoush, J. (2011), Teaching Language through Literature: Designing Appropriate Classroom Activities. ASA University Review, 5 (2): 283-297. 


\section{APPENDICES}

\section{Appendix A:}

Questionnaire for FC students

1. Do you think reading English literature can improve your language?

$$
\text { Yes } \square \quad \text { No } \square
$$

2. Name the mandatory English language course(s) you are required to take. (don't give code number)

3. Do you have any fixed text book/ course content for these English courses?

Yes $\square \quad$ No $\square$

4. Does your teacher prescribe handouts for every new language lesson instead of a fixed textbook?

5. Do you have any literature piece in your language syllabus?

$$
\text { No } \square
$$

6. Name some literary text that is included in your English language course.

7. Did the literature pieces in the syllabus develop your reading, writing, speaking and listening skills in English?

8. Do you think these literature pieces are difficult to understand?

$$
\begin{aligned}
& \text { difficult to understand? } \\
& \text { Yes } \square \quad \text { No } \square
\end{aligned}
$$

9. State some problems you faced understanding these literary texts.

10. Do you think the literature in your syllabus is culturally very remote?

Yes $\square \quad$ No $\square$

11. Do you think English translation from Bangla literature or World literature in English would serve as better texts for learning English?

$$
\text { Yes } \square \quad \text { No } \square
$$

12. Has the literature texts in your syllabus improved your vocabulary?

Yes $\square \quad \mathrm{No} \square$

13. Do you think these literary texts have improved your English grammar?

14. What aspects of English grammar did you learn in these literary texts?

15. Do you enjoy doing grammar in the English language class?

Yes $\square \quad$ No $\square$

16. If your answer is "no" why did you find the language classes boring?

17. Do you think only studying grammar can improving your English?

$$
\text { Yes } \square \quad \text { No } \square
$$

18. State some problems you faced learning English from the non-literary materials used in class.

19. Which do you think is important to make language classes more fun and effective? Replacing more Literature in the syllabus $\square \quad$ Changing Teachers' Teaching Approach $\square \quad$ Both $\square$

20. Do your teachers make you do language activities based on the literary texts?

21. Do these activities involve grammatical, vocabulary, reading, speaking, listening and writing tasks?

22. Which method do you think your teacher uses in the language class? Lecture Based (teacher-centred) $\square \quad$ Activity/ Task Based (student-centred) $\square$ Both $\square$

23. Do you think including more language based activities on literary texts in class will improve your English?

24. Do you think you language learning would be more effective if your teachers gave extensive reading / writing assignments for home?

$$
\text { Yes } \quad \text { No } \square
$$


25. Do you think your language materials represent original English language?

$$
\text { Yes } \square \quad \text { No } \square
$$

26. Would it be more fun learning English if your texts included these - songs, comic strips, films, poster illustrations, advertisements, diary writing, jokes, travelogues, anecdotes, picture poems, play lets, brochures, recipes, manuals, receipts, prescriptions, checklists, announcements, sports report, weather forecast, etc. instead of a grammar book?

$$
\text { Yes } \square \quad \text { No } \square
$$

Appendix B:

Questionnaire for FC teachers

1. Do you think English literature can improve the language of your students?

Yes $\square \quad$ No $\square$

2. Do you have any literature in the language syllabus?

$$
\text { Yes } \square \quad \text { No } \square
$$

3. Do you use literary texts from the cannon? Name some literary texts that you use in the English language.

4. Did these literary texts develop your students' reading, writing, speaking and listening skills?

5. Are these difficult for your students to understand?

$$
\text { Yes } \square \quad \text { No } \square
$$

6. Briefly state some problems your students face studying these literary texts.

7. Do you think the literature used in your language syllabus is culturally remote from your students?

8. In this regard do you think English translations from Bangla literature or World literature in English would serve as better texts for our learners?

9. $\quad$ Explain why?

$$
\text { Yes } \square \quad \text { No } \square
$$

10. Has the literature in the language syllabus improved their vocabulary?

11. Do you think these literary texts improved your students' grammar?

$$
\text { Yes } \square \quad \text { No } \square
$$

12. Do you feel teaching grammar will improve your students' English?

$$
\text { Yes } \square \quad \text { No } \square
$$

13. How do you think language teacher should teach grammar with literary texts?

14. Which do you think is important to make language learning more effective? Replacing more Literature in the syllabus $\square \quad$ Changing Teachers' Teaching Approach and focus to $\square \quad$ Language-based approach $\square \quad$ All of these $\square$

15. Do you make students do language-based activities with literary texts?

$$
\text { Yes } \square \quad \text { No } \square
$$

16. Do these literary materials involve grammatical, vocabulary, reading, speaking, listening and writing tasks?

17. Which teaching method do you use in class?

$$
\text { Yes } \square \quad \text { No } \square
$$
Lecture Based (teacher-centred)
Activity/ Task Based (student-centred) $\square$

Both $\square$

18. Including more language based activities on incentive reading materials of literary texts in class will improve theEnglish standard of your students, do you agree?

$$
\text { Yes } \square \quad \text { No } \square
$$

19. Do you think language learning would be more effective if your students were given extensive reading / writing assignments for home work?

$$
\text { Yes } \square \quad \text { No } \square
$$


20. Do your English textbook / materials contain more traditional English language materials known as "referential materials?

$$
\text { Yes } \square \quad \text { No } \square
$$

21. What do you understand by "literary" or "representational" texts?

22. Do you think English teaching would be more effective if your materials contained the followings contents, known as literature with a small ' 1 ' - songs, films, comic strips, poster illustrations, advertisements, diary writing, jokes, travelogues, anecdotes, picture poems, play-lets, brochures, recipes, manuals, receipts, prescriptions, checklists, announcements, sports report, weather forecast, etc.?

23. Explain why you think so.

$$
\text { Yes } \square \quad \text { No } \square
$$

24. What do your students do more in your English class?

Listen to you lecture $\square \quad$ Students are engaged in solving language tasks $\square$

Both $\square$

25. Do you give a lot of reading/writing homework for English?

$$
\text { Yes } \square \quad \text { No } \square
$$

26. Do you follow daily/weekly/monthly lesson plans and the three stages of reading: pre-reading, while reading and post reading teaching English?

$$
\text { Yes } \square \quad \text { No } \square
$$

27. Which do you feel is required for improving the level of English of your students? Extensive reading homework $\square \quad$ Intensive language based activities for class work $\square \quad$ Both $\square$

28. Which do you think is important for English classroom teaching?
Lecturing $\square \quad$ Language based activities on literary texts $\square \quad$ Both $\square$

29. Including more literature, reading and class activities in the syllabus will improv the level of the students' English, do you agree?

$$
\text { Yes } \square \quad \text { No } \square
$$

\section{Appendix C:}

Questionnaire for EM students

1. Which area are you specializing in? (tick one)
Literature
ELT \& Linguistics
both Language and Literature

2. What do you think should be your number one priority/objective specializing in English? (Tick only one.)

Read, write, speak, listen, understand and use the language accurately $\square$

Learn the concepts of English language teaching $\square$

Interpret literary texts critically and apply literary theory $\square$

Comprehend Linguistics conceptions and its application

3. Name some literary texts/courses that you enjoyed reading. (Please don't give code numbers.)

4. Do you believe that reading English literature can improve your language?

5. If your answer is "yes", tell why you think literature can improve your language.

6. Did the literature courses in your syllabus develop your reading, writing, speaking and listening skills in English?

$$
\text { Yes } \square \quad \text { No } \square
$$

7. If your answer is "yes", how and why do you think this is possible?

8. Do you think the selection in your syllabus is too difficult to understand because most of them are written long time ago?

$$
\text { Yes } \square \quad \text { No } \square
$$

9. State some problems you faced understanding these literary texts.

10. Do you think these literature text in your syllabus are culturally very remote from yours?

$$
\text { Yes } \square \quad \text { No } \square
$$


11. Do you think students specializing in English Literature / ELT \& Linguistics are both weak in terms of language competency in Bangladesh?

$$
\text { Yes } \square \quad \text { No } \square
$$

12. In which area do you feel students are weaker on their language competency? Students Specializing in Literature $\square$

Students Specializing in ELT \& Linguistics $\square$

13. Students in Bangladesh specializing in literature are better at
Literary competence $\square$
Linguistic competence
None of these $\square$

14. What do you think is the reason behind this?

15. Students in our country specializing in Linguistics \& ELT have more

Linguistic competency $\square \quad$ Literary competency $\square \quad$ none of these $\square$

16. What do you think is the reason behind this?

17. Do you think knowledge of literary terms, movements, theory and its application can increase students' linguistics competency?

18. Why do you think so?

$$
\text { Yes } \square \quad \text { No } \square
$$

19. Do you think learning the methods and approaches of ELT / Linguistics concepts and theories can improve students' quality of English in Bangladesh?

20. What may be the reasons?

$$
\text { Yes } \square \quad \text { No } \square
$$

21. There is less focus in language in our literature class and that is why students' quality in English is not improving. Do you agree?

$$
\text { Yes } \square \quad \text { No } \square
$$

22. Students specializing in ELT \& Linguistics courses mainly learn concepts and theories which do not actually improve students' language acquisition. That is why students specializing in this area lack linguistic competence in English. Do you agree?

$$
\text { Yes } \square \quad \text { No } \square
$$

23. Do you agree that English translation from Bangla literature / World literature in English / non canonical texts would be better selections for students specializing in English in our country?

$$
\text { Yes } \square \quad \text { No } \square
$$

24. If your answer is "yes", tell why you feel this way.

25. Do you think a lot of exposure / extensive reading of literature can also improve students' English grammar and vocabulary?

$$
\text { Yes } \square \quad \text { No } \square
$$

26. What aspects of English grammar do think you have acquired from reading these literary pieces?

27. Do you think our students at university level are still weak in English because there is not enough language focus in the literature classes?

$$
\text { Yes } \square \quad \text { No } \square
$$

28. Which method does your teacher use to teach you in class?

Lecture Based (teacher-centred)

Activity/ Task Based (student-centred) $\square$

Both $\square$

29. Which approach do you think would be a better English class for us?

Replacing more Literature in the syllabus

Changing Teachers' Teaching Approach $\square$

Both $\square$

30. Which method do you think would be the best approach of teaching English at the university level (Literature/ Linguistics \& ELT) in Bangladesh to ensure linguistic competence?

Language-based $\square \quad$ Literature as content $\square \quad$ Personal enrichment $\square \quad$ All of them $\square$ 
31. Do you think if teachers in the literature class focused more language based activities / emphasized on intensive reading activities on the literary texts rather than only giving lectures, the language competence of the students would increase?

$$
\text { Yes } \square \quad \text { No } \square
$$

32. Do you think language learning would be more motivating and effective if your teachers provided extensive reading / writing assignments for homework?

$$
\text { Yes } \square \quad \text { No } \square
$$

33. Do you think introducing stylistics would develop students' linguistic competence and also literary competence for original critical analysis of literary texts?

$$
\text { Yes } \square \quad \text { No } \square
$$

34. Any suggestions how English learning can be more fun and effective at advanced level?

\section{Appendix D:}

Questionnaire for EM teachers

$1 . \quad$ Which area do you teach?

Literature $\square \quad$ ELT \& Linguistics $\square \quad$ both Language and Literature
2. $\quad$ What should be the number one priority/objective of our students specializing in English in Bangladesh?

Read, write, speak, listen, understand and use the language accurately $\square$

Learn the concepts of English language teaching $\square$

Interpret literary texts critically and apply literary theory

Comprehend Linguistics conceptions and its application $\square$

3. Name some literary texts/courses that you teach. (Please do not give code numbers.)

4. Do you believe that English literature can improve students' language?

$$
\text { Yes } \square \quad \text { No } \square
$$

6. If your answer is "yes", explain how literature can improve learners' language.

7. Do literature courses/texts in the syllabus develop the four skills of your students in English?

8. If your answer is "yes", how and why do you think this is possible?

9. Do you think the selection in the syllabus is too difficult for your students to understand because most of them are written long time ago?

$$
\text { Yes } \square \quad \text { No } \square
$$

10. State some problems you faced teaching these literary texts to your students in the class.

11. Do you think these literature text in the syllabus are culturally very remote for your students?

$$
\text { Yes } \square \quad \text { No } \square
$$

12. Do you think students specializing in English Literature / ELT \& Linguistics are both weak in terms of language competency in Bangladesh?

$$
\text { Yes } \square \quad \text { No } \square
$$

13. In which area do you feel students are weaker in their language competency? Students Specializing in Literature $\square$ Students Specializing in ELT \& Linguistics $\square$

14. Students in Bangladesh specializing in literature have more
Literary competence $\square$
Linguistic competence $\square$
None of these $\square$

15. What do you think is the reason behind this?

16. Students in our country specializing in Linguistics \& ELT have more

Linguistic competency $\square \quad$ Literary competency $\square \quad$ None of these $\square$

17. Explain why you think so.

18. Do you think knowledge of literary terms, movements, theory and its application can increase students' linguistics competency?

Yes $\square$

19. Why do you think so? 
20. Do you think learning the methods and approaches of ELT / Linguistics concepts and theories can improve students' quality of English in Bangladesh?

21. What may be the reasons?

$$
\text { Yes } \square \quad \text { No } \square
$$

22. There is less focus in language-based activities in our literature class and that is why students' quality in English is not improving. Do you agree?

$$
\text { Yes } \square \quad \text { No } \square
$$

23. Students specializing in ELT \& Linguistics courses mainly learn concepts and theories which do not actually improve students' language acquisition. That is why students specializing in this area lack linguistic competence in English in our country. Do you agree?

$$
\text { Yes } \square \quad \text { No } \square
$$

24. Do you agree that English translation from Bangla literature / World literature in English / non canonical texts would be better selections for students specializing in English in our country?

$$
\text { Yes } \square \quad \text { No } \square
$$

25. If your answer is "yes", tell why you feel this way.

26. Do you think a lot of exposure / extensive reading of literature can also improve students' English grammar and vocabulary?

$$
\text { Yes } \square \quad \text { No } \square
$$

27. What aspects of English grammar do think your students acquired from reading these literary pieces?

28. Do you think your students at university level are still weak in English because there is not enough language focus in the literature classes?

$$
\text { Yes } \square \quad \text { No } \square
$$

29. Which method do you use to teach your students in class?

Lecture Based (teacher-centred)

Activity/ Task Based (student-centred) $\square$

Both $\square$

30. Which approach do you think would be a better English class for your students? Include language based activities in literature syllabus $\square$

Changing teachers' teaching approach $\square$

Both $\square$

31. Which method do you think would be the best approach of teaching English at the university level (Literature/ Linguistics \& ELT) in Bangladesh to ensure your students' linguistic competence?

Language based $\square$ Literature as content $\square$ Personal enrichment $\square \quad$ All of them $\square$

32. If English teachers in the literature class focused more language based activities / emphasized on intensive reading activities rather than only giving lectures, the language competence of the students would increase?

$$
\text { Yes } \square \quad \text { No } \square
$$

33. Do you think language learning would be more motivating and effective if you provided extensive reading / writing assignments for homework for your students?

$$
\text { Yes } \square \quad \text { No } \square
$$

34. Do you think introducing stylistics would develop students' linguistic competence and also literary competence for original critical analysis of literary texts?

$$
\text { Yes } \square \quad \text { No } \square
$$

35. If your answer is 'no', explain why you think this would not be so effective for students in Bangladesh?

36. How do you teach in class?

Only lecture $\square$

Students do language-based task on the literary texts $\square$

Both $\square$

37. Do you give a lot of reading/writing homework for English?

$$
\text { Yes } \square \quad \mathrm{No} \square
$$


32| ELT Worldwide Vol. 2 No. 2 October 2015

38. Do you refer to the stylistics / linguistic features of the literary text while lecturing/teaching in the class?

Yes $\square$

No $\square$

39. Do you follow daily/weekly/monthly lesson plans and the three stages of reading: pre-reading, while reading and post reading teaching in the class?

$$
\text { Yes } \square
$$

40. Which do you feel is required for improving the level of English of your students? Extensive reading/writing homework $\square$

Intensive language-based activities for class work

Both $\square$

41. Which do you think is important for English classroom teaching? Lecturing $\square \quad$ language based activities on literary texts $\square \quad$ Both $\square$

42. Any suggestions how English learning can be more fun and effective at advanced level? 